\title{
PENGEMBANGAN ALAT UKUR KESANTUNAN BAHASA INDONESIA DALAM INTERAKSI SOSIAL BERSEMUKA
}

\author{
Zamzani, Tadkiroatun Musfiroh, Siti Maslakhah, Ari Listyorini, Yayuk Eny R. \\ Fakultas Bahasa dan Seni Universitas Negeri Yogyakarta \\ email: zamzani@uny.ac.id
}

\begin{abstract}
This study aims to (1) develop an instrument to measure politeness in Indonesian, (2) conduct a small-scale tryout of the instrument, and (3) develop the instrument into a book. The research subjects comprised Indonesian speakers consisting of students, university students, teachers, lecturers, and other speakers classified on the basis educational background, age, sex, geographical location, and ethnic group. The data were collected through FGD, tests, and interviews. The data were analyzed using the qualitative and quantitative descriptive techniques. The findings show that polite speech acts can be classified on the basis of the topics and functions. Formal face-to-face speech acts can be those in teaching and learning, formal meetings, other academic topics, traditional ceremonies, transactions, negotiations, and public services. Degrees and characteristics of politeness are attributable to a variety of factors.
\end{abstract}

Keywords: measurement instrument, language politeness, face-to-face social interaction

\section{PENDAHULUAN}

Kesantunan berbahasa memiliki peran penting dalam membina karakter positif penuturnya, sekaligus menunjukkan jati diri bangsa. Walaupun hampir mustahil membuat generalisasi kesantunan dalam semua wilayah, alat ukur penentu kesantunan dalam situasi formal baik lisan maupun tertulis serta situasi nonformal (yang tidak menjangkau wilayah intimate) dapat dibuat dan diperlukan keberadaannya. Alat ukur ini akan sangat membantu mengatasi "bias komunikasi" terutama yang timbul akibat perbedaan kultur setempat dan lintas sosial penutur. Alat ukur ini akan membantu keberadaan bahasa Indonesia sebagai alat pembina karakter penuturnya.

Kesantunan (politeness) merupakan perilaku yang diekspresikan dengan cara yang baik atau beretika. Kesantunan merupakan fenomena kultural, sehingga apa yang dianggap santun oleh suatu kultur mungkin tidak demikian halnya dengan kultur yang lain. Tujuan kesantunan, termasuk kesantunan berbahasa, adalah membuat suasana berinteraksi menyenangkan, tidak mengancam muka, dan efektif. Rasa hormat sering dihubungkan dengan kesantunan, meskipun merupakan fenomena berbeda. Rasa hormat mengacu pada rasa segan yang kita tunjukkan pada orang lain melalui nilai yang mereka miliki, seperti status, usia, dan sebagainya. Kesantunan merupakan hal yang umum untuk menunjukkan perhatian pada orang lain. Antara rasa hormat dan kesantunan dapat dimanifestasikan melalui tingkah laku sosial maupun cara-cara kebahasaan, misalnya saja kita 
dapat mengungkapkan rasa hormat kita dengan berdiri saat seseorang yang memiliki status yang lebih tinggi masuk ruangan, atau dengan menunjukkan kesantunan dengan memegang pintu tetap terbuka saat seseorang akan keluar ruangan.

Dalam kesantunan, konsep akan 'muka' menjadi gagasan utama. Seseorang dituntut untuk memahami kebutuhan akan 'muka' orang lain saat berinteraksi atau berkomunikasi. Saat kita berinteraksi, kita harus menyadari adanya dua jenis 'muka' yang mengacu pada kesantunan. Brown dan Levinson membedakan dua jenis 'muka', yaitu positive face, yang berarti menunjukkan solidaritas, dan negative face, yang menunjukkan hasrat untuk tidak diganggu dalam tindakannya. Selain itu, ada dua jenis kesantunan yang menjadi perhatian saat kita berinteraksi dengan orang lain, yaitu positive politeness, yang ditandai dengan penggunaan bahasa yang informal dan menawarkan pertemanan. Di sisi lain negative politeness ditandai oleh penggunaan formalitas bahasa, mengacu pada perbedaan dan ketidaklangsungan.

Kesantunan dapat dilihat dalam berbagai berspektif. Pertama, kesantunan sebagai fenomena linguistik: banyak studi mengenai kesantunan difokuskan pada level realisasi ujaran. Walter (1979) mendefinisikan fenomena ini sebagai cara menginvestigasi seberapa banyak kesantunan ditekan dari strategi tindak tutur. Fenomena ini melihat kesantunan dalam tingkat permukaan, yakni menekankan pada penggunaan bentuk bahasa dari tindak tutur itu sendiri. Kedua, kesantunan sebagai fenomena pragmatik: pada tingkat ini, kesantunan dianggap sebagai sebuah strategi yang digunakan oleh pembicara untuk dapat mencapai tujuan yang diinginkan. Dengan kata lain, penggunaan bentuk ba- hasa tertentu secara kontekstual untuk mencapai tujuan si pembicara. Konsep kesantunan ini kemudian berkembang menjadi berbagai teori, yang dapat dikategorikan ke dalam lima teori kesantunan berbahasa, yakni teori relevansi, prinsip sopan santun, prinsip kesantunan rasional dan muka, prinsip kerja sama, prinsip kesantunan formal, dan prinsip tenggang rasa. Ketiga, kesantunan sebagai fenomena sosiolinguistik: kesantunan sosiolinguistik mengacu pada penggunaan bahasa yang perlu disesuaikan dengan tujuan komunikasi. Dalam ceramah atau dialog, diterapkan kesopanan sehingga pembicara tidak menyinggung orang lain. Bidang ilmiah, disebut retorik. Bidang wacana, dipilih jenis penceritaan, pemaparan, argumentasi atau persuasi.

Satuan verbal yang digunakan untuk kesantunan berbentuk kata, gabungan kata, kalimat, dan peribahasa. Kesantunan berbahasa dipengaruhi oleh faktor status, jenis kelamin, usia, dan hubungan kekerabatan. Makna kesantunan merefleksikan latar budaya yang dianut penutur dengan berorientasi pada sistem kepercayaan, sistem mata pencaharian, hubungan kekerabatan, stratifikasi sosial, dan sistem pernikahan. Faktor-faktor yang memengaruhi kesantunan menuntut dibuatkan skala kesantunan dari perspektif pragmatik seperti skala opsional, skala kelangsungan tutur, dan skala jarak sosial. Selain itu, kesantunan berbahasa Indonesia terkait dengan faktor sosial, budaya, dan kontekstual yang menjadi penandanya. Oleh karena kesantunan berbahasa sendiri bergantung pada sosial budaya, norma dan aturan suatu tempat, nilai atau aturan satu budaya dapat berbeda dengan budaya lain. Namun demikian, dalam kesantunan berbahasa diperlukan strategi-strategi kesantunan agar komunikasi dapat berjalan dengan 
baik, sehingga tidak mengancam 'muka' orang lain.

Penelitian tahun II ini dapat dimanfaatkan secara khusus untuk pedoman penilaian dan ukuran untuk mengukur derajat kesopanan atau kesantunan dari masing-masing individu berdasarkan bentuk-bentuk tuturan yang disajikan dalam alat ukur kesantunan bahasa Indonesia dalam tuturan formal bersemuka. Dari hasil ini diketahui bahwa tuturan-tuturan yang dijadikan pilihan jawaban memiliki skor yang berbeda-beda, dari skor ini dapat diketahui bagaimana derajat kesantunan dari masing-masing individu.

Selain tujuan praktis, hasil penelitian tahun II ini dapat digunakan sebagai (1) acuan untuk mengukur kesopanan dalam bertindak tutur formal bersemuka, (2) gambaran alat ukur kesantunan formal bersemukan, dan (3) acuan mengukur derajat kesantunan atau kesopanan pada pengguna bahasa Indonesia dalam berbagai kelas sosial.

Adapun urgensi penelitian ini berhubungan langsung dengan komunikasi. Bahasa sebagai wahana kebudayaan, termasuk di dalamnya kebudayaan berkomunikasi, mengisyaratkan bahwa dalam suatu bahasa ada pranata tertentu yang khas dalam kegiatan berbahasa. Peristiwa komunikasi (berwacana) dengan suatu bahasa dapat "terganggu" akibat peserta komunikasi menggunakan pranata kebudayaan yang berbeda.

Fenomena sopan santun tidak dapat dilepaskan dari pranata kebudayaan sebuah bahasa. Penggunaan bahasa dapat menunjukkan kebudayaan, nilai-nilai yang dianut, dan keyakinan agama seseorang. Melalui bahasa, dapat diketahui karakter seseorang, seperti sifat terbuka atau tidaknya, jalan pikiran, sopan santun, bahkan kejujurannya (Kawulusan, 1998).
Sebagai bagian dan pembawa budaya, bahasa Indonesia memiliki kriteria kesantunan yang tidak selamanya sama dengan budaya bahasa lain. Kesantunan dalam bahasa Indonesia sangat mungkin berbeda dengan kesantunan dalam bahasa Inggris, Arab, Cina, Perancis, Jerman, dan berbeda pula dengan kesantunan dalam bahasa daerah.

Sebagai sebuah fenomena relatif, sopan-santun tidak mudah untuk digeneralisasikan. Sopan dan santun dalam suatu kultur belum tentu bernilai sama dalam kultur yang lain. Sapaan yang bernilai kesantunan tinggi dalam suatu budaya, mungkin justru tidak dikenal dalam budaya yang lain. Meskipun demikian, ada ciri-ciri universal dalam kesantunan berbahasa yang dapat diterapkan dalam banyak budaya.

Acuan kesantunan berbahasa dengan bahasa Indonesia memiliki fungsi strategis. Pertama, penutur bahasa Indonesia akan memiliki "aturan" berbahasa. Kedua, penutur bahasa Indonesia memiliki kesempatan untuk melakukan refleksi diri apakah tuturannya sudah sesuai dengan kaidah kesantunan bahasa. Ketiga, para pendidik memiliki pegangan untuk memberikan pembelajaran kesantunan berbahasa. Keempat, acuan kesantunan berbahasa dapat beriringan dengan aturan berbahasa secara baik dan benar (dalam konteks formal).

Kegiatan berbahasa yang santun mensyaratkan terpenuhinya beberapa kriteria. Pertama, harus memenuhi cooperative principle yakni kejelasan, kecukupan unsur, kebenaran isi, kerelevansian dengan topik (Levinson, 1983). Kedua, implikatur yang terpahami (lihat Grice, 1975; Parker, 1986, Wardhaugh, 1986). Ketiga, memenuhi prinsip kesantunan berbicara (lihat Leech, 1983; Mey, 1993). Keempat, me-

Pengembangan Alat Ukur Kesantunan Bahasa Indonesia dalam Interaksi Sosial Bersemuka 
menuhi prinsip saling tenggang Rasa (lihat Azis, 2007), dan memenuhi prinsip konteks.

Fenomena di atas menunjukkan bahwa saat ini, sopan santun berbahasa memperoleh perhatian. Meskipun demikian, fakta menunjukkan perilaku verbal saat ini, dinilai mulai tidak memperhatikan nilai kesopanan dan kesantunan berbahasa, pun dalam berkomunikasi melalui telepon dan handphone. Ketiadaan sapaan, kata penghalus, topik yang tidak pantas, pilihan kata, cara berbicara yang tidak memerhatikan pola pergiliran bicara, bicara menyakiti, kritis pedas, instruksi bossy, pemerasan verbal, intimidasi, ancaman, merupakan sebagian contoh fenomena riil berbahasa di lapangan. Kebutuhan akan acuan berperilaku verbal yang memenuhi kaidah sopan santun pun semakin dirasa mendesak.

Penelitian ini berusaha menjembatani kondisi di atas. Dengan penelitian ini, kondisi di atas di atas akan dapat diatasi. Adapun manfaat dan keutamaan penelitian ini adalah sebagai berikut.

(1) Hasil penelitian dapat digunakan sebagai refleksi bagi penutur bahasa Indonesia, dari berbagai strata sosial, jenis kelamin, latar belakang pendidikan, dan profesi.

(2) Alat ukur yang dihasilkan dapat dijadikan acuan dalam bertindak tutur bahasa Indonesia yang santun, baik dalam situasi formal, konsultatif, maupun casual, baik lisan maupun nonlisan.

(3) Alat ukur yang dihasilkan dapat dijadikan pedoman bagi pendidik (guru dan dosen) dalam mendidik siswa dan mahasiswa agar berbahasa secara santun serta menangani kasus ketidaksantunan berbicara, berpidato, dan bersms yang dilakukan peserta didik.

(4) Alat ukur yang dihasilkan menjadi pengayaan penelitian dan teori pragmatik, sosiolinguistik, dan analisis wacana.

\section{METODE}

Penelitian ini mempergunakan pendekatan riset dan pengembangannya (Research and Development. Penelitian ini bertujuan untuk mengembangkan alat ukur kesantunan. Alat ukur divalidasi oleh ahli dan pengguna dalam bentuk desk evaluation dan FGD. Alat ukur kesantunan juga diujicobakan dalam bentuk tes dalam lapangan terbatas. Alat ukur berupa tes yang telah direvisi diolah dalam bentuk buku.

Subjek penelitian ini adalah penutur bahasa Indonesia yang sudah dituntut berbahasa secara santun. Subjek pada tahun kedua ini adalah mahasiswa, guru, dosen, dan pengguna bahasa lain yang diklasifikasi berdasarkan satuan pendidikan, jenis kelamin, dan suku (juga etnis). Lokasi penelitian ini adalah Yogyakarta (Gunung kidul, Sleman, Kota, Kulon Progo dan Bantul). Wilayah-wilayah yang dihuni warga dari multisuku dan multietnis juga dipilih selain lembaga pendidikan dan kampus. Kriteria yang digunakan setidaktidaknya meliputi satu dari tiga syarat, yakni penutur bahasa Indonesia aktif, latar belakang pendidikan, dan anggota suatu masyarakat atau wacana tutur tertentu, khususnya komunitas bahasa Indonesia.

Teknik pengumpulan data yang digunakan adalah FGD, tes, dan wawancara apabila dibutuhkan. FGD dilakukan untuk menemukan kesepahaman tes sebelum diberikan kepada pengguna. Tes dilakukan sekaligus dengan memberikan skor pada tiap jawaban untuk menentukan derajat kesantunan. Wawancara dilakukan terhadap subjek dengan memberikan pertanyaan yang berkaitan dengan kesantunan bahasa. 
Alat tes kesantunan dievaluasi dengan melakukan FGD antara tim peneliti dengan ahli di bidang pragmatik, sosiolinguistik, wacana, dan guru. Uji validitas yang dilakukan dengan menguji validasi kunci yang telah dirumuskan tim peneliti dan sekaligus untuk mencari keselarasan atau kecocokan jawaban dari tim peneliti dengan jawaban tim ahli. Alat tes diujicobakan secara terbatas kepada calon pengguna (35 orang). Alat tes dibuat dalam bentuk tes objektif telah digradasikan berdasarkan hasil FGD. Uji luas akan dilakukan sebelum draf kesantunan dicetak menjadi buku. Hasil tes kesantunan dan indikator kesantunan kembali dicek dan diperbaiki untuk menemukan bobot setiap indikator. Alat tes diperbaiki baik secara konseptual maupun redaksional. Analisis redaksional meliputi unsur kebahasaan alat tes, unsur ketepatan dengan indikator, ketepatan konteks, dan kelengkapan semua unsur. Analisis ini menghasilkan sebuah draf buku Mengukur Kesantunan Berbicara yang mudah dan menarik untuk dibaca.

Alir penelitian tahun kedua tampak pada bagan 1

Alat Tes Kesantunan Bahasa Indonesia Formal Bersemuka

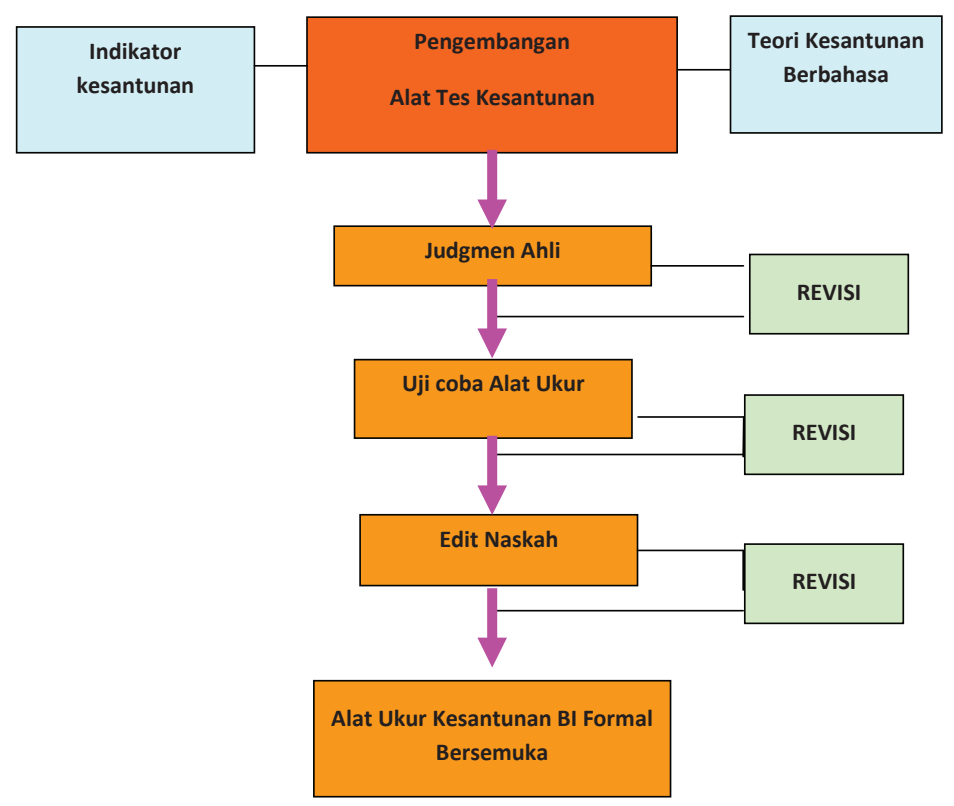

Bagan 1. Alir Penelitian tahun kedua

Analisis data dilakukan dengan metode kualitatif dan kuantitatif. Analisis kualitatif dilakukan untuk menganalisis data FGD. Analisis kuantitatif digunakan untuk analisis item guna mengetahui mutu masing-masing item dan kehandalan perangkat tes. Analisis dilakukan dengan teknik analisis item klasik. Perbaikan atau revisi dilakukan dengan menganulir butir-butir yang tidak layak.

\section{HASIL DAN PEMBAHASAN Bentuk Tindak Tutur Berkesantunan}

Hasil penelitian pada tahun pertama menunjukkan bahwa bentuk tindak tutur yang bernilai kesantunan dapat dikategorikan berdasarkan topik-topik dan fungsinya. Berdasarkan topiknya, tindak tutur bahasa Indonesia formal bersemuka yang ditemukan dikategorikan ke dalam lima topik, yakni tindak tutur dalam 
proses belajar mengajar, pertemuan resmi, topik akademik lain, upacara adat dan seremonial, serta transaksi, negosiasi, dan pelayanan publik.

Matriks 1: Tindak Tutur BI Formal Bersemuka

\begin{tabular}{lllll}
\hline PBM & $\begin{array}{l}\text { Pertemuan } \\
\text { Resmi }\end{array}$ & $\begin{array}{l}\text { Akademik } \\
\text { Lain }\end{array}$ & $\begin{array}{l}\text { Upacara Adat } \\
\text { \& Seremonial }\end{array}$ & $\begin{array}{l}\text { Transaksi, Ne- } \\
\text { gosiasi, Pelay- } \\
\text { anan Publik }\end{array}$ \\
\hline $\begin{array}{l}\text { Memberi } \\
\text { komentar }\end{array}$ & $\begin{array}{l}\text { Mengajukan } \\
\text { protes }\end{array}$ & Mempersilakan & Melucu & Bertanya \\
$\begin{array}{l}\text { Mengajar } \\
\text { Mengkritik }\end{array}$ & Menolak & Mengomentari & Permintaan & Menanggapi \\
Penyajian & $\begin{array}{l}\text { Mengajukan } \\
\text { penilaian }\end{array}$ & $\begin{array}{l}\text { Menjawab } \\
\text { pertanyaan }\end{array}$ & $\begin{array}{l}\text { Menyampaikan } \\
\text { informasi }\end{array}$ & $\begin{array}{l}\text { Menunjukkan } \\
\text { ketersinggu- } \\
\text { ngan }\end{array}$ \\
Menyuruh & $\begin{array}{l}\text { Memberikan } \\
\text { tanggapan }\end{array}$ & Berterima kasih & Bertanya & $\begin{array}{l}\text { Memberikan } \\
\text { kesaksian }\end{array}$ \\
Meminta Ijin & Berpendapat & Memberikan & & Menawar \\
& Mempersilakan & Menegur & & Berargumentasi \\
Bertanya & Menjawab & & & Meminta \\
& $\begin{array}{l}\text { pertanyaan } \\
\text { Menilai }\end{array}$ & & & Menagih \\
& $\begin{array}{l}\text { Meminta } \\
\text { Menegur }\end{array}$ & & & Mengingatkan \\
& & & &
\end{tabular}

Berbagai tuturan yang mengemban fungsi bahasa di atas terjadi di dalam kelas sosial (seperti karyawan dengan karyawan) dan di luar kelas sosial (guru dengan murid). Bentuk tuturan dan konteks kelas tuturan di atas menentukan kategori kesopanan sebuah tuturan. Protes anak terhadap guru dapat dikategorikan sebagai tuturan yang tidak atau kurang sopan, terutama apabila melanggar prinsip kesopanan. Meskipun demikian, penilaian tentang kesopanan sebuah bentuk tuturan ditentukan juga dengan identitas kelas sosial responden.

Kategori di atas dijadikan dasar untuk menyusun instrumen kesantunan bahasa Indonesia formal bersemuka. Pemakaiankategoriinidengan pertimbang- an untuk mempermudah pemahaman konteks bagi pengguna instrumen ini nantinya. Artinya, dengan pembagian pertopik konteks bahasan, pengguna langsung bisa menidentifikasi konteksnya berdasarkan topik-topik tuturan tersebut.

\section{Pengembangan Instrumen Menjadi Alat Ukur Kesantunan}

Langkah yang dilakukan dalam penelitian ini meliputi dua tahap, yaitu penyamaan persepsi antarpeneliti dan merevisi draf tentatif yang dihasilkan dalam penelitian tahun pertama. Revisi dilakukan terhadap draf tentatif tahun pertama dan menghasilkan draf dengan bentuk seperti tes UKBI (Uji Keterampilan Bahasa Indonesia). Draf ini perlu direvisi kembali menjadi model UKBI 
dengan pertimbangan agar pengguna tidak terjebak dalam pilihan jawaban yang hampir sama, khususnya pada jawaban dengan kategori sangat sopan dan sopan atau sangat tidak sopan dan tidak sopan. Dengan skala linkert, pilihan jawaban hanya berada pada kategori tersebut di atas. Mengingat alat ukur ini untuk mengukur derajat kesantunan pengguna, diperlukan kategori nilai yang pasti. Berdasarkan pertimbangan itulah model yang dipilih adalah memberikan skor pada masing-masing pilihan. Dengan memberikan skor ini diharapkan ukuran santun atau tidak santun pada diri pengguna dapat dihitung berdasarkan pilihan jawaban yang ada dan dikategori berdasarkan jumlah yang ada. Pertimbangan yang lain adalah agar kuisioner yang ada lebih mudah dikerjakan oleh pemakai. Dari jumlah skor yang ada tersebut baru dicocokkan dengan kategori kesantunan yang sudah disediakan. Dengan demikian, dapat dinilai derajat kesantunan masing-masing penggunanya.

Penyusunan angket tetap berdasarkan kelima topik dalam matriks tindak tutur bahasa Indosesia formal bersemuka. Matrik tersebut diturunkan menjadi beberapa bentuk tuturan dengan disertai pilihan jawaban yang memiliki derajad kesantunan secara berjenjang. Bentuk-bentuk tuturan tersebut adalah pengembangan dari instrumen yang telah ditemukan pada tahun pertama. Instrumen tersebut dikembangkan dengan bentuk tuturan yang disertai konteks. Kelima topik pembahasan dijabarkan menjadi 50 bentuk soal, masing-masing memiliki 5 pilihan jawaban. Bentuk soal disusun dengan sistematika dan setting yang sama. Hal ini untuk mempermudah respoden memahami isi jawaban. Apabila setting berbeda kemungkinan munculnya perbedaan per- sepsi sangat besar sehingga berdampak pada penentuan pilihan jawaban.

Pilihan jawaban yang tersedia bersifat berjenjang, mengingat derajat kesantunan masing-masing individu berbeda-beda. Karena derajat kesantunan yang berbeda itulah diperlukan ukuran untuk menilai kadar kesantunannya. Ukuran ini didasarkan pada penilaian atau skor di masing-masing pilihan yang ada. Skor berjenjang yang dimaksudkan adalah sebagai berikut. 5 : untuk pilihan sangat santun; 4: untuk pilihan santun; 3 : untuk pilihan agak santun; 2 : untuk pilihan tidak santun; 1 : untuk pilihan sangat tidak santun.

Penjabaran untuk pilihan tersebut disajikan dalam contoh soal berikut.

1. Ibu Guru menemukan kenyataan bahwa Bimo mencontek pekerjaan Anjas. Ibu Guru mengetahuinya karena menemukan lembar jawab mereka sama persis jawabannya. Bu guru memanggil mereka untuk membuat konfirmasi. Ketika Bimo ditanya mengenai hal ini, dia berkata:

a. "Maaf Bu, saya tidak sempat belajar minggu ini."

b. "Iya Bu, karena saya tidak belajar Bu."

c. "Memangnya tidak boleh ya Bu? Saya kan tidak sempat belajar."

d. "Tidak apa-apa ya Bu, sekali ini saja, namanya juga usaha."

e. "Gak apa-apa Bu, Bu guru repotrepot amat ngurusin kaya gitu."

Jawaban di atas memiliki gradasi kesantunan yang berjenjang, dari pilihan a merupakan pilihan sangat santun (skor 5), b merupakan pilihan santun (skor 4), c merupakan pilihan agak santun (skor 3), d, merupakan pilihan tidak santun (skor 2), dan e adalah pilihan yang sangat tidak santun (skor 1). Contoh soal di atas dibuat dengan jenjang skor yang bersifat gradasi karena soal di atas menjadi pedoman peneliti untuk mempermudah penyusunan kunci jawaban.

Pengembangan Alat Ukur Kesantunan Bahasa Indonesia dalam Interaksi Sosial Bersemuka 
Tahap selanjutnya melakukan pengacakan soal-soal tersebut. Soalsoal yang sudah diacak ini yang akan dipakai sebagai soal untuk mengukur kesantunan bahasa Indonesia formal bersemuka. Penyusunan angket yang sudah diacak dibuat menyerupai soalsoal model UKBI. Dengan perevisian angket menjadi model UKBI diharapkan diperoleh ukuran yang valid dan penyekoran yang sesuai. Jadi, pemakai tidak hanya memilih jawaban, tetapi juga memberikan skor.

Skor-skor tersebut menjadi pedomanan penilaian pengguna. Pengguna bisa menghitung derajad kesantunannya dengan menjumlah keseluruhan skor yang ada, kemudian menentukan kategorinya berdasarkan jumlahnya. Berdasarkan Jumlah skor yang ada, diklasifikasi dengan kategori skala sangat santun, santun, tidak santun dan sangat tidak santun. Adapun skala penyekoran tersebut adalah sebagai berikut.

(1)Skala sangat Santun : skor 250-200

(2)Skala santun : skor 199-150

(3)Skala tidak santun : skor 149-100

(4)Skala sangat tidak santun: skor $<100$

\section{Kategorisasi Bentuk-bentuk Kesantun- an Berdasarkan Skala Kesantunan}

Penilaian dalam alat ukur ini dikategori dalam empat skala penilaian seperti tercantum di atas. Masing-masing memiliki karakeristik berbeda tergantung pada topik pembicaraan. Karakteristiknya adalah sebagai berikut.

\section{Karakteristik Kesantunan Formal Ber- semuka}

Dalam topik ini kegiatan bertutur terdiri dari lima bagian, yaitu memberi komentar, menolak mengajar, mengritik penyajian, menyuruh, meminta izin, dan bertanya. Berikut akan disajikan karakteristik tuturan berdasarkan kategori sangat santun, santun, tidak santun dan sangat tidak santun.
Kategori Tuturan Sangat santun: Bentuk-bentuk tuturan dalam pilihan jawaban responden yang termasuk dalam kategori sangat santun (skor 5) apabila memiliki ciri-ciri sebagai berikut: (1) penghargaan terhadap orang lain, (2) menunjukan rasa rendah hati, tidak sombong, (3) teguran yang jujur, namun halus, (4) pujian jujur, (5) penolakan dengan kata "maaf", (6) perintah dengan nada pertanyaan, (7) penolakan dengan nada pertanyaan (antara guru dan murid), dan (8) memberikan dukungan dengan tulus.

Kategori Tuturan Santun: Bentukbentuk tuturan dalam pilihan jawaban responden yang termasuk dalam kategori santun (skor 4 dan 3) apabila memiliki ciri-ciri sebagai berikut: (1) tuturan yang menunjukan realita yang benar, apa adanya, (2) mengandung unsur ketegasan atu mendisiplinkan, (3) kritik yang membangun, (4) bertujuan untuk mendidik, (5) penggunaan diksi yang sangat lugas, (6) kritikan dengan menggunakan kata "maaf", (7) pengakuan yang jujur, apa adanya, dan (8) memberikan sindiran secara halus.

Kategori Tuturan Tidak Santun: Bentuk-bentuk tuturan dalam pilihan jawaban responden yang termasuk dalam kategori tidak santun (skor 2) apabila memiliki ciri-ciri sebagai berikut: (1) menegur dengan diksi yang kurang halus, (2) pembelaan terhadap pebuatan salah, (3) tidak menghargai orang lain, (4) menonjolkan dirinya sendiri, (5) mempermalukan orang lain di muka umum, (6) merendahhkan orang lain, (7) superior, (8) kejujuran yang menyakiti orang lain, (9) mengejek, dan (10) berbicara tidak sesuai situasi.

Kategori Tuturan Sangat Tidak Santun: Bentuk-bentuk tuturan dalam pilihan jawaban responden yang termasuk dalam kategori sangat tidak santun (skor 1) apabila memiliki ciri-ciri sebagai berikut: (1) menunjukan rasa marah ke- 
pada murid, (2) menyombongkan diri, (3) superior dan suka menghakimi, (4) fitnah, (5) bercanda untuk menjatuhkan teman lain, (6) menegur dengan diksi kasar, (7) bahasa vulgar, dan (8) sindiran yang menjatuhkan murid di depan umum.

Berikut disajikan bentuk soal, jawaban, dan penilaian seperti di dalam angket.

Ibu Guru menemukan kenyataan bahwa Bimo mencontek pekerjaan Anjas. Ibu Guru mengetahuinya karena menemukan lembar jawab mereka sama persis jawabannya. $\mathrm{Bu}$ guru memanggil mereka untuk membuat konfirmasi. Ketika Bimo ditanya mengenai hal ini, dia berkata:

a."Iya $\mathrm{Bu}$, karena saya tidak belajar Bu." (4)

b. "Maaf Bu, saya tidak sempat belajar minggu ini." (5)

c."Tidak apa-apa ya Bu, sekali ini saja, namanya juga usaha." (2)

d."Memangnya tidak boleh ya Bu? Saya kan tidak sempat belajar."(3)

e."Gak apa-apalah Bu, Bu guru repotrepot amat ngurusin kaya gitu."(1)

Berdasarkan bentuk tuturan dalam pilihan jawaban, dapat diidenti- fikasi berdasarkan skor yang diberikan responden. Pada soal 1 misalnya, skor 5 berada pada pilihan jawaban yang sangat santun dengan ciri bahwa bentuk jawaban yang diberikan mengandung unsur kejujuran, cara penyampaiannya dengan diksi yang halus, pengungkapan maaf disampaikan karena benar-benar merasa bersalah. Sementara skor 4 dan 3 diberikan pada pilihan jawaban yang mengandung unsur kejujuran tanpa pengungkapan maaf walaupun pelaku mengakui kesalahannya, untuk skor 2 disampaikan dengan diksi yang vulgar, jujur, tetapi tidak ada perasaan bersalah dari pelaku. Sementara itu, untuk skor 1 disampaikan dengan diksi vulgar dan menyakitkan.

\section{Karakeristik Umum Bentuk Kesantunan Bahasa Indonesia Formal Bersemuka} Pertemuan Resmi dalam Topik Proses Belajar Mengajar

Kegiatan yang termasuk dalam topik kegiatan resmi dalam PBM, yaitu proses belajar mengajar di kelas, ujian, diskusi, presentasi makalah, tanya jawab di kelas, meminta izin, menegur dan menasihati dalam PBM, mengonfirmasi kedatangan dan mengritik atau memberi masukan. 
Tabel 1: Indikator Kesantunan dalam Topik Pertemuan Resmi PBM

\begin{tabular}{|c|c|c|c|c|c|}
\hline No. & Aktivitas & Sangat santun & santun & Tidak santun & $\begin{array}{c}\text { Sangat tidak } \\
\text { santun }\end{array}$ \\
\hline 1. & $\begin{array}{l}\text { Bertanya / } \\
\text { konfirmasi } \\
\text { mengenai } \\
\text { suatu hal }\end{array}$ & $\begin{array}{l}\text { - Menggunakan } \\
\text { kata MOHON, } \\
\text { MAAF, dan } \\
\text { MOHON MAAF } \\
\text { - Tidak } \\
\text { berprasangka } \\
\text { buruk pada orang } \\
\text { lain }\end{array}$ & $\begin{array}{l}\text { - Menggunakan } \\
\text { kata MAAF } \\
\text { - Pilihan diksi tepat }\end{array}$ & $\begin{array}{l}\text { Berprasangka } \\
\text { buruk pada } \\
\text { orang lain }\end{array}$ & $\begin{array}{l}\text { - Menuduh } \\
\text { - Fitnah }\end{array}$ \\
\hline 2. & Menolak & $\begin{array}{l}\text { - Ucapan diberikan } \\
\text { secara tulus tidak } \\
\text { terpaksa } \\
\text { - Jujur / sportif }\end{array}$ & $\begin{array}{l}\text { - Penolakan halus } \\
\text { secara eksplisit } \\
\text { - Jujur apa adnya } \\
\text { - Argumen tepat }\end{array}$ & $\begin{array}{l}\text { - Tidak tulus } \\
\text { - Penolakan } \\
\text { dengan nada } \\
\text { tinggi } \\
\text { - Mencari-cari } \\
\text { alasan }\end{array}$ & $\begin{array}{l}\text { - Berbohong } \\
\text { - Penolakan kasar }\end{array}$ \\
\hline 3. & $\begin{array}{l}\text { Mengomen- } \\
\text { tari pendapat } \\
\text { / mengkritik } \\
\text { hasil karya } \\
\text { orang lain }\end{array}$ & $\begin{array}{l}\text { - Menggunakan } \\
\text { kata MAAF } \\
\text { - Tidak } \\
\text { berprasangka } \\
\text { buruk pada orang } \\
\text { lain } \\
\text { - Tidak } \\
\text { menyinggung } \\
\text { perasaan } \\
\text { - Memberi saran } \\
\text { disertai solusi } \\
\text { dilakukan dengan } \\
\text { diksi halus }\end{array}$ & $\begin{array}{l}\text { - Memberi saran } \\
\text { tidak secara } \\
\text { langsung } \\
\text { - Pilihat kata tepat } \\
\text { - Memberi kritik } \\
\text { yang membangun }\end{array}$ & $\begin{array}{l}\text { - Memberi saran } \\
\text { secara langsung } \\
\text { - Tidak } \\
\text { menghargai } \\
\text { pendapat orang } \\
\text { lain } \\
\text { - Menyindir } \\
\text { - Menuduh orang } \\
\text { lain }\end{array}$ & $\begin{array}{l}\text { - Memberi } \\
\text { komentar / } \\
\text { saran / masukan } \\
\text { secara langsung } \\
\text { dengan bahasa } \\
\text { yang kasar } \\
\text { - Menjatuhkan } \\
\text { orang lain di } \\
\text { depan umum }\end{array}$ \\
\hline 4. & $\begin{array}{l}\text { Mengajukan } \\
\text { usul }\end{array}$ & $\begin{array}{l}\text { - Menggunakan } \\
\text { kata terima kasih } \\
\text { - Tidak } \\
\text { merendahkan } \\
\text { pendapat orang } \\
\text { lain } \\
\text { - Tidak sombong } \\
\text { - Menghargai orang } \\
\text { lain }\end{array}$ & $\begin{array}{l}\text { - Memberi } \\
\text { alternatif pilihan } \\
\text { dengan tidak } \\
\text { memaksa } \\
\text { - Memberikan } \\
\text { argumen yang } \\
\text { tepat }\end{array}$ & $\begin{array}{l}\text { - Mementing-kan } \\
\text { kepentingan } \\
\text { pribadi } \\
\text { - Memaksakan } \\
\text { kehendak } \\
\text { - Melecehkan } \\
\text { orang lain }\end{array}$ & $\begin{array}{l}\text { - Arogan } \\
\text { - Superior } \\
\text { - Sombong }\end{array}$ \\
\hline 5. & $\begin{array}{l}\text { Menegur } \\
\text { siswa/ } \\
\text { mahasiswa }\end{array}$ & $\begin{array}{l}\text { - Menggunakan } \\
\text { kata MAAF } \\
\text { - Dengan diksi yang } \\
\text { tepat } \\
\text { - Teguran yang } \\
\text { membangun }\end{array}$ & $\begin{array}{l}\text { - Teguran secara } \\
\text { langsung } \\
\text { - Diksi tepat } \\
\text { - Jujur apa adanya } \\
\text { - kooperatif }\end{array}$ & $\begin{array}{l}\text { - menyindir } \\
\text { - dilakukan di } \\
\text { depan umum } \\
\text { - tanpa alasan }\end{array}$ & $\begin{array}{l}\text { - teguran dengan } \\
\text { nada kasar } \\
\text { - diksi vulgar } \\
\text { - melecehkan } \\
\text { orang lain di } \\
\text { depan umum }\end{array}$ \\
\hline
\end{tabular}

Topik Akademik Lain Non-PBM

Kegiatan yang termasuk dalam topik kegiatan resmi nonPBM, yaitu Seminar, pertemuan / rapat RT, pertemuan / rapat dasa wisma, pertemuan / rapat pemuda, pertemuan / rapat aparat pemerintah, pertemuan / rapat perusahaan / kantor, pertemuan / rapat resmi lainnya 
Tabel 2: Indikator Kesantunan dalam Topik Pertemuan Resmi Non-PBM

\begin{tabular}{|c|c|c|c|c|c|}
\hline No. & Aktivitas & Sangat santun & santun & Tidak santun & $\begin{array}{c}\text { Sangat tidak } \\
\text { santun }\end{array}$ \\
\hline 1. & $\begin{array}{l}\text { Bertanya / } \\
\text { konfirmasi } \\
\text { mengenai } \\
\text { suatu hal }\end{array}$ & $\begin{array}{l}\text { - Menggunakan } \\
\text { kata MOHON, } \\
\text { MAAF, dan } \\
\text { MOHON MAAF } \\
\text { - Tidak } \\
\text { berprasangka } \\
\text { buruk pada orang } \\
\text { lain }\end{array}$ & $\begin{array}{l}\text { - Menggunakan } \\
\text { kata MAAF }\end{array}$ & $\begin{array}{l}\text { - Menuduh / } \\
\text { berprasangka } \\
\text { buruk pada } \\
\text { orang lain }\end{array}$ & \\
\hline 2. & $\begin{array}{l}\text { Mengucapkan } \\
\text { selamat }\end{array}$ & $\begin{array}{l}\text { - Ucapan diberikan } \\
\text { secara tulus tidak } \\
\text { terpaksa } \\
\text { - Jujur / sportif }\end{array}$ & & - Tidak tulus & $\begin{array}{l}\text { - Memberi } \\
\text { ucapan } \\
\text { karena } \\
\text { terpaksa }\end{array}$ \\
\hline 3. & $\begin{array}{l}\text { Mengomen- } \\
\text { tari } \\
\text { pendapat / } \\
\text { hasil karya } \\
\text { orang lain }\end{array}$ & $\begin{array}{l}\text { - Menggunakan } \\
\text { kata MAAF } \\
\text {-Tidak } \\
\text { berprasangka } \\
\text { buruk pada orang } \\
\text { lain } \\
\text { - Tidak } \\
\text { menyinggung } \\
\text { perasaan } \\
\text { - Memberi saran } \\
\text { disertai solusi } \\
\text { - Tidak dilakukan } \\
\text { secara vulgar }\end{array}$ & $\begin{array}{l}\text { - Memberi saran } \\
\text { tidak secara } \\
\text { langsung }\end{array}$ & $\begin{array}{l}\text { - Memberi } \\
\text { saran secara } \\
\text { langsung } \\
\text { - Tidak } \\
\text { menghargai } \\
\text { pendapat } \\
\text { orang lain } \\
\text { - Menyindir } \\
\text { - Menuduh } \\
\text { orang lain }\end{array}$ & $\begin{array}{l}\text { - Memberi } \\
\text { komentar/ } \\
\text { saran / } \\
\text { masukan } \\
\text { secara } \\
\text { langsung } \\
\text { dengan } \\
\text { bahasa } \\
\text { yang kasar }\end{array}$ \\
\hline 4. & $\begin{array}{l}\text { Mengajukan } \\
\text { usul }\end{array}$ & $\begin{array}{l}\text { - Menggunakan } \\
\text { kata terima kasih } \\
\text { - Tidak } \\
\text { merendahkan } \\
\text { pendapat orang } \\
\text { lain } \\
\text { - Tidak sombong }\end{array}$ & $\begin{array}{l}\text { - Memberi } \\
\text { alternatif } \\
\text { pilihan } \\
\text { dengan tidak } \\
\text { memaksa }\end{array}$ & $\begin{array}{l}\text { - Mementing- } \\
\text { kan } \\
\text { kepentingan } \\
\text { pribadi } \\
\text { - Memaksakan } \\
\text { kehendak } \\
\text { - Sombong }\end{array}$ & \\
\hline 5. & $\begin{array}{l}\text { Menegur } \\
\text { orang lain / } \\
\text { bawahan }\end{array}$ & $\begin{array}{l}\text { - Menggunakan } \\
\text { kata MAAF }\end{array}$ & & & \\
\hline
\end{tabular}

Topik Akademik Lain Non-PBM

Kegiatan yang termasuk dalam topik akademik lain non PBM, yaitu transaksi buku di sekolah, urusan penunjukkan pengurus sekolah, OSPEK, Konsultasi skripsi antara dosen dan ma- hasiswa, ujian skripsi (bidang akademis) bimbingan lomba dari pembimbing/guru pada siswa, bimbingan konseling, kegiatan ekstrakurikuler sekolah, diskusi kelas, praktikum dan pelatihan dan seminar hasil penelitian. 
Tabel 3: Indikator Kesantunan dalam Topik Akademik Lain Non-PBM

\begin{tabular}{|c|c|c|c|c|c|}
\hline No. & Aktivitas & Sangat santun & santun & $\begin{array}{c}\text { Tidak } \\
\text { santun }\end{array}$ & $\begin{array}{c}\text { Sangat tidak } \\
\text { santun }\end{array}$ \\
\hline 1. & Penolakan & $\begin{array}{l}\text { - menggunakan } \\
\text { kata maaf } \\
\text { - menggunakan } \\
\text { kata mohon } \\
\text { - menggunakan } \\
\text { kata coba } \\
\text { - memberi saran } \\
\text { alternatif }\end{array}$ & $\begin{array}{l}\text { - lugas } \\
\text { - memberi saran } \\
\text { alternatif }\end{array}$ & $\begin{array}{l}\text { - bahasa } \\
\text { kasar }\end{array}$ & $\begin{array}{l}\text { - Menggunakan } \\
\text { bahasa yang kasar } \\
\text { - Menuduh } \\
\text { - Tidak menghargai } \\
\text { orang lain }\end{array}$ \\
\hline 2. & $\begin{array}{l}\text { Merekomen- } \\
\text { dasi }\end{array}$ & $\begin{array}{l}\text { - Memberi } \\
\text { kepercayaan } \\
\text { pada orang lain } \\
\text { - Berpikiran } \\
\text { positif pada } \\
\text { orang lain } \\
\text { - Menggunakan } \\
\text { kata percaya } \\
\text { atau yakin }\end{array}$ & $\begin{array}{l}\text { - Berpikiran } \\
\text { positif pada } \\
\text { orang lain } \\
\text { - Menggunakan } \\
\text { kata percaya } \\
\text { atau yakin }\end{array}$ & $\begin{array}{l}\text { memberi } \\
\text { beban } \\
\text { yang } \\
\text { terlalu } \\
\text { tinggi } \\
\text { pada } \\
\text { orang lain }\end{array}$ & \\
\hline 3. & $\begin{array}{l}\text { Memper- } \\
\text { silakan }\end{array}$ & $\begin{array}{l}\text { - Menggunakan } \\
\text { kata silakan } \\
\text { - Member } \\
\text { kesempatan } \\
\text { terlebih dahulu } \\
\text { kepada orang } \\
\text { yang lebih tua }\end{array}$ & $\begin{array}{l}\text { - Menggunakan } \\
\text { kata mari } \\
\text { - Memberi } \\
\text { kesempatan } \\
\text { terlebih } \\
\text { dahulu } \\
\text { kepada orang } \\
\text { yang lebih tua }\end{array}$ & & \\
\hline 4. & $\begin{array}{l}\text { Mengaju- } \\
\text { kan/ mem- } \\
\text { beri saran }\end{array}$ & & & & \\
\hline 5. & $\begin{array}{l}\text { Mengung- } \\
\text { kapkan } \\
\text { rasa marah }\end{array}$ & $\begin{array}{l}\text { - Memberi } \\
\text { kesempatan } \\
\text { untuk } \\
\text { menjelaskan } \\
\text { alasan }\end{array}$ & $\begin{array}{l}\text { - Memberi } \\
\text { kesempatan } \\
\text { untuk } \\
\text { menjelaskan } \\
\text { alasan }\end{array}$ & - Menuduh & $\begin{array}{l}\text { - Menuduh } \\
\text { - Menggunakan } \\
\text { kata yang kasar }\end{array}$ \\
\hline 6. & Menasehati & $\begin{array}{l}\text { - Menggunakan } \\
\text { kata/ } \\
\text { kalimat yang } \\
\text { membangkitkan } \\
\text { semangat }\end{array}$ & $\begin{array}{l}\text { - Menggunakan } \\
\text { kata/ } \\
\text { kalimat yang } \\
\text { membangkit- } \\
\text { kan semangat }\end{array}$ & & $\begin{array}{l}\text { - Merendahkan } \\
\text { orang lain } \\
\text { - Menggunakan } \\
\text { kata yang kasar }\end{array}$ \\
\hline 7. & Minta izin & $\begin{array}{l}\text { - Menggunakan } \\
\text { kata maaf } \\
\text { - Menggunakan } \\
\text { kalimat Tanya }\end{array}$ & $\begin{array}{l}\text { - Menggunakan } \\
\text { kata maaf } \\
\text { - Menggunakan } \\
\text { kalimat tanya }\end{array}$ & & \\
\hline
\end{tabular}

Kesantunan Formal Bersemuka dalam Topik Transaksi dan Negosiasi

Kegiatan yang termasuk dalam topik transaksi dan negosiasi, adalah Jual beli atau perdagangan, Pelayanan publik di instansi-instansi baik swasta maupun pemerintah, Penawaran barang/produk dan jasa, Penyebaran informasi, Negosiasi harga, Transaksi jual beli dan Konsultasi. 
Tabel 4: Indikator Kesantunan dalam Topik Transaksi dan Negosiasi

\begin{tabular}{|c|c|c|c|c|c|}
\hline No. & Aktivitas & Sangat santun & santun & Tidak santun & $\begin{array}{l}\text { Sangat tidak } \\
\text { santun }\end{array}$ \\
\hline 1. & $\begin{array}{l}\text { Bertanya / } \\
\text { konfirmasi } \\
\text { mengenai } \\
\text { suatu hal/ } \\
\text { barang/benda }\end{array}$ & $\begin{array}{l}\text { - Menggunakan kata } \\
\text { MOHON, MAAF, } \\
\text { dan MOHON } \\
\text { MAAF } \\
\text { - Tidak berprasangka } \\
\text { buruk pada orang } \\
\text { lain }\end{array}$ & $\begin{array}{l}\text { - Menggu- } \\
\text { nakan kata } \\
\text { MAAF }\end{array}$ & $\begin{array}{l}\text { - Menuduh / } \\
\text { berprasangka } \\
\text { buruk pada } \\
\text { orang lain }\end{array}$ & \\
\hline 2. & $\begin{array}{l}\text { Mengucapkan } \\
\text { salam/ } \\
\text { menyapa } \\
\text { konsumen }\end{array}$ & $\begin{array}{l}\text { - Ucapan diberikan } \\
\text { secara tulus tidak } \\
\text { terpaksa } \\
\text { - ramah }\end{array}$ & $\begin{array}{l}\text { - Ucapan } \\
\text { dengan diksi } \\
\text { tepat }\end{array}$ & $\begin{array}{l}\text { - Tidak tulus/ } \\
\text { basa-basi } \\
\text { - Menyapa } \\
\text { dengan ketus }\end{array}$ & $\begin{array}{l}\text { - Memberi } \\
\text { ucapan } \\
\text { karena } \\
\text { terpaksa }\end{array}$ \\
\hline 3. & $\begin{array}{l}\text { Mengomentari } \\
\text { barang/benda } \\
\text { hasil karya } \\
\text { orang lain }\end{array}$ & $\begin{array}{l}\text { - Menggunakan kata } \\
\text { MAAF } \\
\text { - Tidak } \\
\text { menyinggung } \\
\text { perasaan penjual } \\
\text { atau calon pembeli } \\
\text { - Memberi saran } \\
\text { disertai solusi } \\
\text { - dilakukan secara } \\
\text { halus }\end{array}$ & $\begin{array}{l}\text { - Memberi } \\
\text { saran tidak } \\
\text { secara } \\
\text { langsung }\end{array}$ & $\begin{array}{l}\text { - Memberi } \\
\text { saran secara } \\
\text { langsung } \\
\text { - Tidak } \\
\text { menghargai } \\
\text { pendapat } \\
\text { orang lain } \\
\text { - Menyindir } \\
\text { - Menuduh } \\
\text { orang lain }\end{array}$ & $\begin{array}{l}\text { - Memberi } \\
\text { komentar/ } \\
\text { saran / } \\
\text { masukan } \\
\text { secara } \\
\text { langsung } \\
\text { dengan } \\
\text { bahasa } \\
\text { yang kasar }\end{array}$ \\
\hline 4. & $\begin{array}{l}\text { Mengajukan } \\
\text { dan menerima } \\
\text { usulan, } \\
\text { memberi } \\
\text { masukan }\end{array}$ & $\begin{array}{l}\text { - Menggunakan kata } \\
\text { terima kasih } \\
\text { - Menghargai } \\
\text { pendapat orang lain } \\
\text { - Tidak Memaksakan } \\
\text { kehendak }\end{array}$ & $\begin{array}{l}\text { - Memberi } \\
\text { alternatif } \\
\text { pilihan } \\
\text { dengan } \\
\text { tidak mema- } \\
\text { ksa } \\
\text { - Menyaran- } \\
\text { kan dengan } \\
\text { objektif } \\
\text { - Memberikan } \\
\text { penjelasan } \\
\text { apa adanya }\end{array}$ & $\begin{array}{l}\text { - Mmentigkan } \\
\text { target } \\
\text { individu } \\
\text { - Menekan } \\
\text { mengarah } \\
\text { paksaan } \\
\text { - Masukan yang } \\
\text { kurang benar }\end{array}$ & $\begin{array}{l}\text { - Memaksa- } \\
\text { kan } \\
\text { kehendak } \\
\text { - Mementi- } \\
\text { ng-kan } \\
\text { kepenti- } \\
\text { ngan } \\
\text { sendiri } \\
\text { - Berbohong } \\
\text { demi } \\
\text { kepenti- } \\
\text { ngan } \\
\text { sendiri }\end{array}$ \\
\hline 5 & $\begin{array}{l}\text { Menegur atau } \\
\text { menasehati } \\
\text { orang } \\
\text { lain/calon } \\
\text { konsumen }\end{array}$ & $\begin{array}{l}\text { - Menggunakan kata } \\
\text { MAAF } \\
\text { - Disampaikan } \\
\text { dengan kata santun } \\
\text { - Menjelaskan } \\
\text { dengan benar }\end{array}$ & $\begin{array}{l}\text { - Disampai- } \\
\text { kan secara } \\
\text { implisit } \\
\text { - Disampai- } \\
\text { kan dengan } \\
\text { diksi yang } \\
\text { tepat } \\
\text { - objektif }\end{array}$ & $\begin{array}{l}\text { - Teguran } \\
\text { secara } \\
\text { eksplisit } \\
\text { - Diksi kurang } \\
\text { tepat, ironi } \\
\text { - Ada unsur } \\
\text { kebohongan }\end{array}$ & $\begin{array}{l}\text { - } \text { Teguran } \\
\text { secara } \\
\text { keras/ kasar } \\
\text { - Diksi kasar } \\
\text { - berbohong }\end{array}$ \\
\hline
\end{tabular}

Kesantunan Formal Bersemuka dalam Topik Upacara Adat dan Ceremonial

Kegiatan yang termasuk dalam topik upacara adat dan ceremonial, yaitu Situasi dalam upacara pernikahan atau upacara adat lainnya, memberi- kan sambutan, mempersilahkan tamu, membuka acara, menasehati, menyanjung atau memuji, memberikan informasi, berkomentar, menutup acara, dan bertanya. 
Tabel 5: Indikator Kesantunan dalam Topik Transaksi dan Negosiasi

\begin{tabular}{|c|c|c|c|c|c|}
\hline No. & Aktivitas & Sangat santun & santun & Tidak santun & $\begin{array}{c}\text { Sangat tidak } \\
\text { santun }\end{array}$ \\
\hline 1 & $\begin{array}{l}\text { Bertanya / } \\
\text { konfirmasi }\end{array}$ & $\begin{array}{l}\text { - Menggunakan } \\
\text { kata MOHON, } \\
\text { MAAF, dan } \\
\text { MOHON } \\
\text { MAAF } \\
\text { - Tidak } \\
\text { berprasangka } \\
\text { buruk pada } \\
\text { orang lain }\end{array}$ & $\begin{array}{l}\text { - Mengguna- } \\
\text { kan kata } \\
\text { MAAF }\end{array}$ & $\begin{array}{l}\text { - Menuduh / } \\
\text { berprasangka } \\
\text { buruk pada } \\
\text { orang lain }\end{array}$ & $\begin{array}{l}\text { - Fitnah } \\
\text { - tidak } \\
\text { menghargai } \\
\text { orang lain } \\
\text { - superior }\end{array}$ \\
\hline 2 & $\begin{array}{l}\text { Mengucap- } \\
\text { kan salam/ } \\
\text { menyapa }\end{array}$ & $\begin{array}{l}\text { - Ucapan } \\
\text { diberikan } \\
\text { secara tulus } \\
\text { tidak terpaksa } \\
\text { - ramah }\end{array}$ & $\begin{array}{l}\text { - Ucapan } \\
\text { dengan } \\
\text { diksi tepat }\end{array}$ & $\begin{array}{l}\text { - Tidak tulus/ } \\
\text { basa-basi } \\
\text { - Menyapa } \\
\text { dengan ketus }\end{array}$ & $\begin{array}{l}\text { - Memberi } \\
\text { ucapan karena } \\
\text { terpaksa }\end{array}$ \\
\hline 3 & $\begin{array}{l}\text { Mengomen- } \\
\text { tari orang/ } \\
\text { keadaan }\end{array}$ & $\begin{array}{l}\text { - Menggunakan } \\
\text { kata MAAF } \\
\text { - Tidak } \\
\text { menyinggung } \\
\text { perasaan orang } \\
\text { lain } \\
\text { - Memberi saran } \\
\text { disertai solusi } \\
\text { - dilakukan } \\
\text { secara halus }\end{array}$ & $\begin{array}{l}\text { - Memberi } \\
\text { saran tidak } \\
\text { secara } \\
\text { langsung } \\
\text { - Komentar } \\
\text { dengan } \\
\text { diksi halus }\end{array}$ & $\begin{array}{l}\text { - Memberi } \\
\text { komentar } \\
\text { secara } \\
\text { langsung } \\
\text { - Tidak } \\
\text { menghargai } \\
\text { pendapat } \\
\text { orang lain } \\
\text { - Menyindir }\end{array}$ & $\begin{array}{l}\text { - Memberi } \\
\text { komentar/ } \\
\text { saran / } \\
\text { masukan } \\
\text { secara } \\
\text { langsung } \\
\text { dengan bahasa } \\
\text { yang kasar } \\
\text { - Melecehkan } \\
\text { orang lain }\end{array}$ \\
\hline 4 & $\begin{array}{l}\text { Memberikan } \\
\text { masukan }\end{array}$ & $\begin{array}{l}\text { - Menggunakan } \\
\text { kata terima } \\
\text { kasih } \\
\text { - Menghargai } \\
\text { pendapat } \\
\text { orang lain } \\
\text { - Tidak } \\
\text { Memaksakan } \\
\text { kehendak }\end{array}$ & $\begin{array}{l}\text { - Memberi } \\
\text { alternatif } \\
\text { pilihan } \\
\text { dengan } \\
\text { tidak } \\
\text { memaksa } \\
\text { - Menyaran- } \\
\text { kan dengan } \\
\text { objektif } \\
\text { - Memberikan } \\
\text { penjelasan } \\
\text { apa adanya }\end{array}$ & $\begin{array}{l}\text { - Mmentigkan } \\
\text { target } \\
\text { individu } \\
\text { - Menekan } \\
\text { mengarah } \\
\text { paksaan } \\
\text { - Masukan } \\
\text { yang kurang } \\
\text { benar }\end{array}$ & $\begin{array}{l}\text { - Memaksakan } \\
\text { kehendak } \\
\text { - Mementingkan } \\
\text { kepentingan } \\
\text { sendiri } \\
\text { - Berbohong } \\
\text { demi } \\
\text { kepentingan } \\
\text { sendiri }\end{array}$ \\
\hline 5 & $\begin{array}{l}\text { Mempersilah- } \\
\text { kan tamu }\end{array}$ & $\begin{array}{l}\text { - Diksi halus } \\
\text { - Mendahulukan } \\
\text { Tamu } \\
\text { - Menjelaskan } \\
\text { dengan cara } \\
\text { atau prosedur } \\
\text { yang benar }\end{array}$ & $\begin{array}{l}\text { - Diksi tepat } \\
\text { - Diberi } \\
\text { penjelasan }\end{array}$ & $\begin{array}{l}\text { - Disampaikan } \\
\text { dengan diksi } \\
\text { vulgar } \\
\text { - Penyampaian } \\
\text { berbelit-belit }\end{array}$ & $\begin{array}{l}\text { - Diksi vulgar } \\
\text { - Tidak jelas } \\
\text { penyampaian- } \\
\text { nya }\end{array}$ \\
\hline
\end{tabular}




\section{SIMPULAN}

Alat ukur tes kesantunan disusun dievaluasi dengan melakukan FGD antara tim peneliti dengan ahli-ahli di bidang pragmatik, sosiolinguistik, dan ahli wacana, dan juga dengan guru-guru se-DIY. FGD dilakukan dengan cara para ahli dan para guru tersebut memberikan skor pada jawaban yang sudah diacak oleh tim peneliti. Mereka memberi nilai 5 untuk derajad kesantunan sangat santun, nilai 4 untuk derajad santun, nilai 3 untuk agak santun, nilai 2 untuk tidak santun, dan nilai 1 untuk sangat tidak santun. Penyekoran dilakukan dengan pertimbangan bahwa tujuan pengisian angket bukan sekadar mencari bentuk tuturan yang santun, tetapi membuat peringkat tingkat kesantunan dari bentuk tuturan sangat santun, santun tidak santun dan sangat tidak santun. Dengan demikian, dapat dirumuskan skor-skor tingkat kesantunan yang ada sebagai nilai dari wujud tingkat kesantunannya. Uji validitas dilakukan dengan menguji validasi kunci yang telah dirumuskan serta dengan mencari keselarasan jawaban dari tim peneliti dengan tim ahli. Alat tes diujicobakan secara terbatas kepada calon pengguna, yang diwakili oleh guru, dosen, mahasiswa dan pemerhati budaya dalam waktu bersamaan karena keterbatasan waktu.

Alat ukur kesantunan ini terdiri dari lima topik bidang interaksi formal bersemuka. Topik-topik tersebut, yaitu topik dalam proses belajar mengajar, topik pertemuan resmi, topik akademik lain non-PBM, topik upacara adat dan seremonial, dan topik transaksi dan negosiasi. Setiap topik berjumlah lima puluh soal dengan lima pilihan jawaban tiap soalnya. Pengguna alat tes ini harus memilih satu jawaban yang dianggap tepat. Jawaban dicocokkan dengan kunci alat tes tersebut dan dijumlah hasil nilainya. Hasilnya derajat kesantunan pengguna dapat dilihat dari perolehan nilai yang didapatkan. Kategori sangat santun dengan skor 250-200, santun dengan skor 199-150, tidak santun dengan skor 149-100, dan sangat tidak santun dengan skor $<100$.

\section{UCAPAN TERIMA KASIH}

Akhirnya, kami ingin menyampaikan ucapan terima kasih kepada berbagai pihak yang telah memungkinkan terselenggaranya penelitian tahap kedua ini. Pertama, ucapan terima kami sampaikan kepada Direktur DP2M Dikti yang menyeponsori penelitian dengan menghibahkan dana lewat program penelitian Hibah Bersaing lewat Dipa Universitas Negeri Yogyakarta. Kedua, ucapan terima kasih kami sampaikan kepada Rektor UNY lewat Ketua Lembaga Penelitian UNY yang telah memfasilitasi penelitian ini sehingga semuanya dapat berjalan sesuai dengan ketentuan. Selanjutnya, ucapan terima kasih kami sampai kepada sejawat dosen dan responden penelitian, staf administrasi Lemlit UNY, dan berbagai pihak lain yang tidak dapat disebut satu per satu. Harapan kami penelitian ini ada manfaatnya kepada berbagai pihak yang terkait dengan penggunaan bahasa di Indonesia.

\section{DAFTAR PUSTAKA}

Aziz, Aminuddin. 2007. "Aspek-aspek Budaya yang Terlupakan dalam Praktek Pengajaran Bahasa Asing" Bandung: UPI.

Brown, P. dan S. C. Levinson. 1987. Politehness: some universals in language usage. Cambridge: Cambridge University Press.

Grice, H. P. 1975. Logic and conversation. Dalam P. Cole dan J.L. Morgan (ed). Syntax and semantics 3: speech acts. NY: Academic Press.

Hymes, D. 1972. Models of the interaction

Pengembangan Alat Ukur Kesantunan Bahasa Indonesia dalam Interaksi Sosial Bersemuka 
of language and social life. Dalam J.J. Gumperz dan D. Hymes (ed). Directions in sociolinguistics: the ethnography of communication. NY: Holt, Rinehart \& Winston.

Leech, Geoffrey. 1993. Prinsip-prinsip Pragmatik (terj: Oka, M.D.D.) Jakarta : Universits Indoensia.

Levinson, Stephen C. 1983. Pragmatics. Cambridge: Cambridge University
Press.

Mey, Jacob. L. 1993. Pragmatics: Introduction. Cambridge : Blackwell Publisher.

Sperber dan Wilson. 1989. Relevance Communication and Cognition. Oxford: Basil:Blackwell.

Wardhaugh, Ronald. 1998. An Introduction to Sociolinguistics. 3rd Edition. Cambridge:Black Well. 